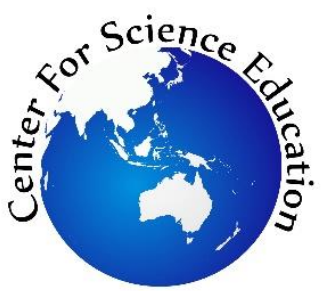

Tersedia online di EDUSAINS
Website: $h$ ttp://journal.uinjkt.ac.id/index.php/edusains

EDUSAINS, 12(2), 2020, 223-232

Research Artikel

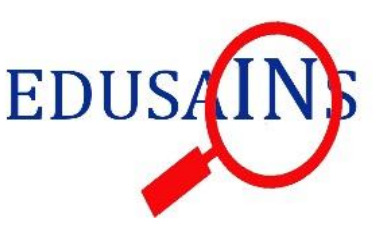

\title{
ASSESING CRITICAL THINKING SKILLS AND MASTERY CONCEPTS: THE CASE OF ECOSYSTEM MATERIAL
}

\author{
PENILAIAN KETERAMPILAN BERPIKIR KRITIS DAN PENGUASAAN KONSEP PADA \\ MATERI EKOSISTEM \\ Lia Junita Harahap*, Rizhal Hendi Ristanto, Ratna Komala \\ Universitas Negeri Jakarta, Indonesia \\ *liajunita52@gmail.com
}

\begin{abstract}
Critical thinking skills and mastery concepts are competencies that measure cognitive aspects. Both of these competencies support each other. This study aims to analyze critical thinking skills and mastery concepts of students in the ecosystem material. This was quantitative research. The sampling technique used Purposive Sampling, namely 60 high school students. Data was collected through the critical thinking skills test and mastery concept of ecosystem tests for students and interviews with the teacher. Based on the analyzed data, the average critical thinking skills and mastery concepts of an ecosystem are 53,15 and 61,10, which are in the low category. This is because students still have difficulty in understanding the basic concepts of ecosystems; students have not understood yet the terms in the ecosystem so that the terms with their meanings are often exchanged which has an impact on the low achievement of students.
\end{abstract}

Keywords: assessment; biological concepts; critical thinking skills; ecosystems; mastery concepts

\section{Abstrak}

Keterampilan berpikir kritis dan penguasaan konsep adalah kompetensi yang mengukur kemampuan kognitif. Kedua kompetensi tersebut saling berkaitan dan mendukung satu sama lain. Penelitian ini bertujuan untuk menganalisis keterampilan berpikir kritis dan penguasaan konsep peserta didik pada materi Ekosistem. Penelitian ini merupakan penelitian kuantitatif. Teknik pengambilan sampel yang digunakan adalah purposive sampling, yaitu 60 peserta didik SMA. Data diperoleh melalui tes tentang keterampilan berpikir kritis dan penguasaan konsep pada materi Ekosistem yang dikerjakan oleh peserta didik dan wawancara dengan guru. Berdasarkan analisis data, rata-rata keterampilan berpikir kritis dan penguasaan konsep materi Ekosistem peserta didik, masing-masing adalah 53,15 dan 61,10. Hasil tersebut termasuk dalam kaegori rendah. Hal ini disebabkan oleh sulitnya peserta didik dalam memahami konsep dasar Ekosistem, belum mengertinya istilahistilah dalam ekosistem sehingga sering terjadi pertukaran istilah dengan maknanya yang berdampak pada rendahnya prestasi belajar siswa.

Kata Kunci: Penilaian; konsep Biologi; keterampilan berpikir kritis; Ekosistem; penguasaan konsep

Permalink/DOI: http:// doi.org/10.15408/es.v12i2.16544 


\section{INTRODUCTION}

One of the skills demanded in the 21st century is critical thinking skills (Geçit \& Akarsu, 2017; Changwong et al., 2018). Critical thinking is the skill of students to analyze their thoughts in making choices, be smart in drawing conclusions, be independent in making decisions and act rationally (Gojkov et al., 2015). Critical thinking is a process whose acquisition requires time. In this process, teachers must be able to adapt the learning methodologies that are appropriate to the characteristics of students or various ways of learning (Bezanilla et al., 2019).

Students who think critically are able to formulate relevant questions, gather relevant information, and evaluate it to reach relevant conclusions (Paul \& Elder, 2007; Permana \& Chamisijatin, 2019; Harahap, Ristanto, \& Komala, 2020a) this is important in the problem-solving process. Students who have critical thinking skills will more easily understand the material, so students' mastery concepts of ecosystem material become richer (Soirwan \& Nyeneng, 2013).

Mastery concept of ecosystems or biology is important to develop in students. The teacher must set mastery standards that must be achieved by all students before they can advance to the next level (Yeh et al., 2019). Mastery of biological concepts is the cognitive ability of students in understanding and mastering the concepts of science through a phenomenon, event, object, or activity related to biological material. Mastery of a concept is needed so that students can explain the relationship between the concepts learned, so mastery of the material becomes more meaningful and can move on to further higher material (Lamidi et al., 2015; Ristanto et al., 2018; Harahap, Ristanto, \& Komala, 2020b).

In recent years, ecosystem damage has increased significantly. Ecosystem is one of the material that taught in high school. Ecosystems are ecological systems formed by the mutual relations of living things with their environment (Komala et al., 2016) Ecosystem damage occurs due to natural factors and human activities. Human behavior that is too exploitative and does not care about the environment such as dumping garbage into rivers results in a decrease in the quality of the ecosystem (Douglas, 2017).

Environmental damage has become an important problem in the $21^{\text {st }}$ century and continues to grow rapidly such as global warming and air pollution (Bonnett, 2016). The development of human population, economy, science, and technology has influenced people's lifestyles. Fast food packaging, junk food produces waste that is difficult to decompose which ultimately ends up in rivers and seas by humans who are not aware of ecosystem damage (Kaushik \& Anubha, 2010). Many students do not realize that their daily behavior or activities can be detrimental to many people, both in the area and in other areas. So the aspects that will be studied in ecosytem material are very important to be taught include ecosystem components, interactions in ecosystems, ecosystem types, energy flow and biogeochemical cycles.

By studying ecosystems, students will be able to realize the importance of ecosystems in various dimensions of human well-being, among others, ecological, socio-cultural, and economic (Crossman et al., 2011; Torkar \& Krašovec, 2019). Therefore, students are required to be able to think critically in facing various environmental problems, not only limited to knowing the problem but being able to act intelligently, make wise decisions and even be able to change or improve the critical thinking of those around them.

Improving critical thinking skills and mastery concepts can be pursued through education so as to shape the human character who has the responsibility and values the sustainability of sustainable development. Educational programs are very important for the development of environmental literacy (Hutcheson et al., 2018), increasing knowledge, and also turning positive attitudes about the environment into behavior. Overcoming the problem of damage to ecosystems requires students to have critical thinking to be able to identify the causes and be able to overcome the problem of damage to the ecosystem. So that the wise attitude of students in utilizing and conserving natural resources will grow. This is same opinion with (Franco et al., 2017; Wilson, 2017) someone 
with critical thinking has more opportunities in his professional, academic, and daily life because he is able to solve problems and make decisions based on reasoning and logic in a regulated way.

Based on this, analysis of critical thinking skills and the mastery concept of ecosystem is needed to determine the role of these two aspects and the problems faced in efforts to achieve the learning objectives of ecosystems in Al-Hasra High School.

\section{METHOD}

This study used quantitative research. The research type used was descriptive research which is descriptively describing student answers based on quantitative data was conducted in June 2018. The population in this study were all grade $\mathrm{X}$ students of Al-Hasra Depok High School consisting of 5 classes, 153 students. The sampling technique used Purposive Sampling, namely class X Science 1 and X Science 2 in the 2018/2019 school year as many as 60 students. This sampling was based on the average score of academic biology abilities of students who are at almost the same level.

The instrument used to measure critical thinking skills is in the form of essay tests and multiple-choice tests to measure students' mastery of the ecosystem concept. Indicators of critical thinking skills in this study were raised from (Facione, 2011) in (Table 1) and mastery concept indicators are raised from the cognitive level of (Anderson et al., 2002) which is a revision of Bloom in (Table 2).

Table 1. Critical Thinking Skills Indicators

\begin{tabular}{|c|c|c|}
\hline Variable & Indicator & Question Description \\
\hline \multirow{6}{*}{$\begin{array}{l}\text { Critical } \\
\text { Thinking } \\
\text { Skills }\end{array}$} & Interpretation & $\begin{array}{l}\text { Interpreting and grouping } \\
\text { food chains into food webs }\end{array}$ \\
\hline & Analysis & $\begin{array}{l}\text { Analyzing interactions } \\
\text { between organisms }\end{array}$ \\
\hline & Inference & $\begin{array}{l}\text { Taking conclusions from one } \\
\text { case about the food chain }\end{array}$ \\
\hline & Evaluation & $\begin{array}{l}\text { Evaluating statements or } \\
\text { opinions about the causes of } \\
\text { energy loss in each trophy of } \\
\text { the energy pyramid }\end{array}$ \\
\hline & Explanation & Explaining the nitrogen cycle \\
\hline & $\begin{array}{l}\text { Self- } \\
\text { Regulation }\end{array}$ & $\begin{array}{lrr}\text { Responding about forest } \\
\text { ecosystems that } \\
\text { increasingly damaged }\end{array}$ \\
\hline
\end{tabular}

Table 2. Mastery of Ecosystem Concepts Indicators

\begin{tabular}{lll}
\hline Variable & Indicator & Question Description \\
\hline Mastery & Remembering & $\begin{array}{l}\text { Recalling the concept of the } \\
\text { ecosystem components }\end{array}$ \\
\cline { 2 - 3 } & Understanding & $\begin{array}{l}\text { Understanding and classifying } \\
\text { types of interactions }\end{array}$ \\
\cline { 2 - 3 } & Applying & $\begin{array}{l}\text { Methods of eradicating pests in } \\
\text { increasing food production }\end{array}$ \\
\cline { 2 - 3 } & Analyzing & $\begin{array}{l}\text { Criticizing the impact of } \\
\text { increasing levels of carbon } \\
\text { dioxide gas in the atmosphere } \\
\text { from motor vehicles, industries } \\
\text { and settlements }\end{array}$ \\
\cline { 2 - 3 } & Evaluating & $\begin{array}{l}\text { Evaluating the causes of growth } \\
\text { of algae and other disturbing } \\
\text { plants to flourish in slow- } \\
\text { flowing rivers }\end{array}$ \\
\hline Creating & $\begin{array}{l}\text { Developing and formulating } \\
\text { several organisms to form a food } \\
\text { chain }\end{array}$ \\
\hline
\end{tabular}

Instruments that have been validated by validators who are experts in their fields are then distributed to students whose answers are then analyzed based on indicators of critical thinking skills and indicators of mastery concept. The data obtained were then analyzed descriptively through tables and percentage diagrams to describe critical thinking skills and mastery concept of ecosystems. The data analysis used was descriptive statistics. The students' critical thinking skills or mastery concepts test results were analyzed using percentage formula by (Purwanto, 2002) where scores obtained by students are divided by maximum score and multiplied by $100 \%$.

\section{RESULTS AND DISCUSSION}

Based on the results of research on critical thinking skills obtained an average of 53.15. It shows that students' critical thinking skills are low. Average acquisition of each indicator of critical thinking skills is shown in (Table 3).

Table 3. Percentage of Critical Thinking Skills

\begin{tabular}{ll}
\hline Indicator & Average \\
\hline Interpretation & 68.92 \\
\hline Analysis & 41.89 \\
\hline Inference & 50.68 \\
\hline Evaluation & 46.62 \\
\hline Explanation & 40.54 \\
\hline Self-Regulation & 70.27 \\
\hline
\end{tabular}

The acquisition of the score in (Table 3) shows that the highest average value of 70.27 is in the 'self-regulation' indicator, while the lowest 
average score of 40.54 is in the 'explanation' indicator. This shows the critical thinking skills of low students. Students are not able to develop answers of the questions. Students prefer to answer with short answers and fill in each question. Based on research that has been done, the percentage of students who are able to think critically is only $19 \%$. The following is a table of some questions and answers from some students and their analysis.

Table 4. Examples of Students' Critical Thinking Skills (Interpretation)

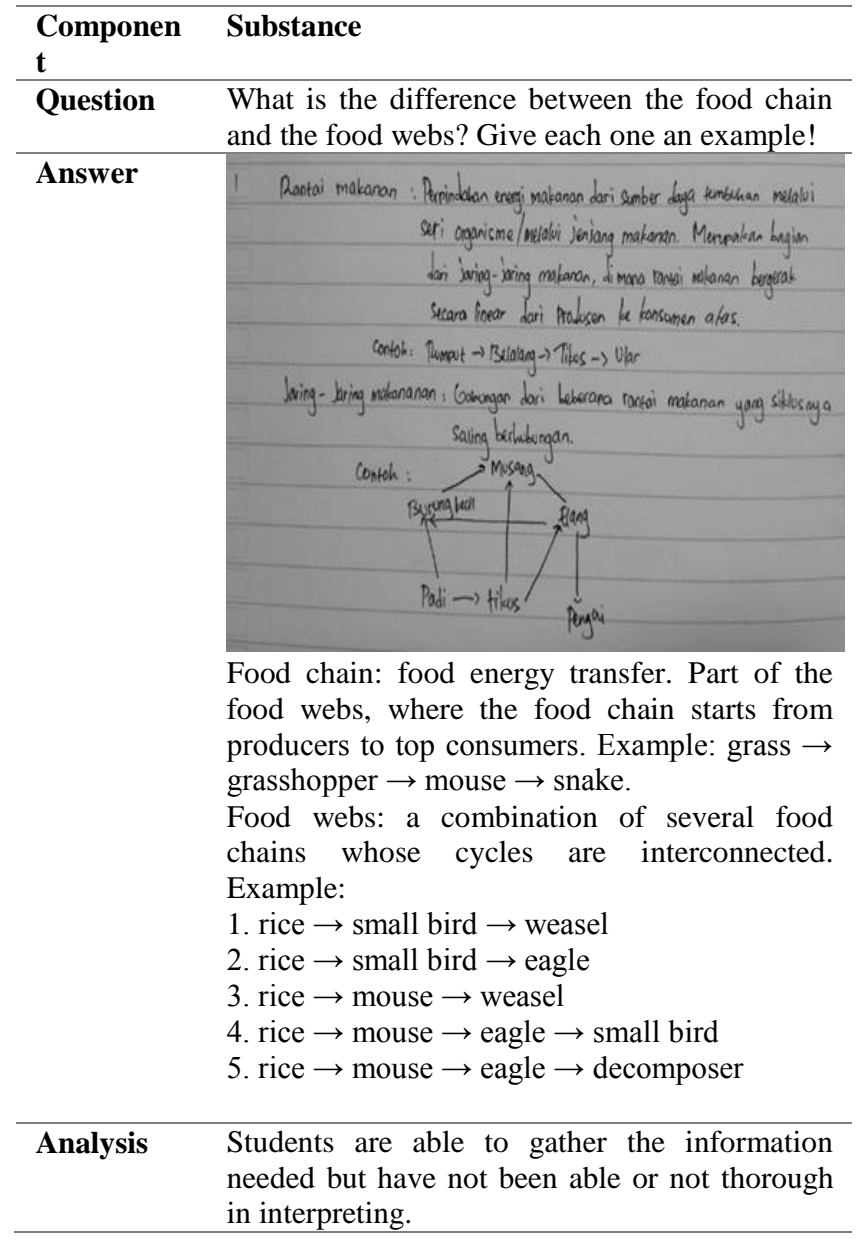

One way to measure students' interpretation skills is through drawing pictures and tables (Nur, 2011). Students' answers to the questions (Table 4) have been able to describe the process of the food chain, but have not been careful in interpreting the direction of the food web arrows, there are still wrong and incomplete directions in the food web example. This shows that students have not been able to think critically because critical thinking is a cognitive activity which means using mental processes such as attention, selection, grouping and assessment.
The ability to interpret is more than translating. Interpretation is the ability to recognize and understand by connecting past knowledge with subsequent knowledge, understanding, grouping, and expressing meaning, as well as connecting between graphs or data with the conditions described (Facione, 2011).

Table 5. Examples of Students' Critical Thinking Skills (Analysis)

\begin{tabular}{ll}
\hline Component & Substance \\
\hline Question & $\begin{array}{l}\text { All living things will always depend on } \\
\text { other living things. Every individual }\end{array}$ \\
& relates to other individuals of the same \\
type and of different types. The following \\
are examples of interactions in the \\
ecosystem
\end{tabular}

a.

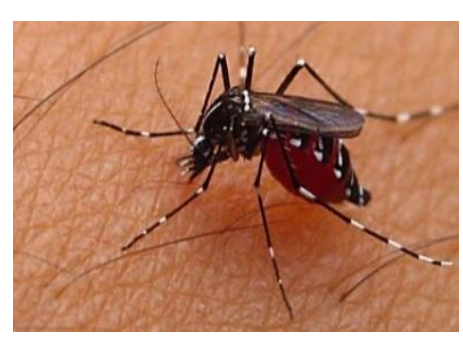

b.

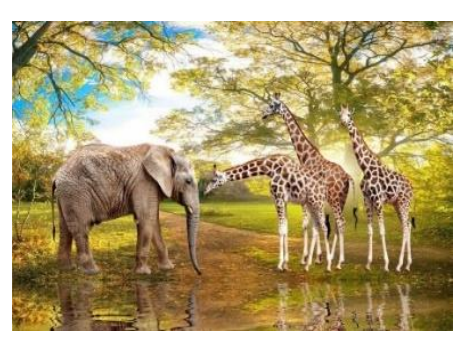

Describe the types of interactions that occur in Figures a and b!

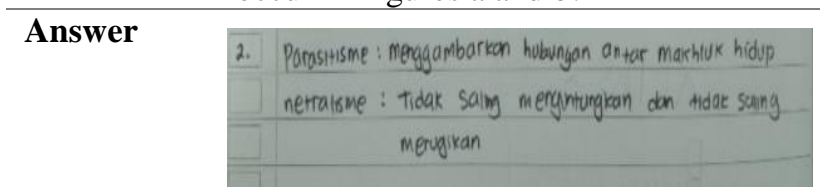

Parasitism: describes the relationship between living things.

Neutralism: not mutually beneficial and not mutually beneficial.

Analysis Students have not been able to recognize opinions, reasons and statements, and do not identify the type of individual or population that is interacting.

Critical thinking is the cognitive and intellectual abilities needed to define, analyze, evaluate, and decide on actions. Based on the answers of students listed in (Table 5) shows that students have not been able to analyze properly. Students are not able to express confidence in answers. This can be seen in the explanation of 
parasitism, students only answer the relationship between living things and do not explain the advantages or disadvantages between living things. The problem in Figure $\mathrm{A}$ is a symbiosis of parasitism because of the interaction between living things that one is lucky (mosquitoes) and the other (humans) loses because mosquitoes suck human blood. Figure B is neutralism because in the same habitat, elephants and some giraffes are not mutually beneficial and do not harm each other, meaning that between organisms do not interfere with each other. So in this case, students' critical thinking is still low, because according to (Fajrianthi et al., 2016) critical thinking skills are skills in providing systematic and organized reasons.

Table 6. Examples of Students' Critical Thinking Skills (Inference)

\begin{tabular}{ll}
\hline $\begin{array}{l}\text { Compone } \\
\text { nt }\end{array}$ & Substance \\
\hline Question & $\begin{array}{l}\text { In the field ecosystem, owls and snakes are } \\
\text { rat eaters. What will happen if these two } \\
\text { prey are eliminated by humans? }\end{array}$ \\
\hline Answer & 3. populafi tikus meningleat . \\
\hline Analysis & $\begin{array}{l}\text { Students have not been able to give reasons, } \\
\text { build meaning, analyze cause and effect } \\
\text { and have not been able to provide } \\
\text { implications from the inferences made. }\end{array}$ \\
\hline
\end{tabular}

Critical thinking is a process that ends in drawing inferences on what will be done. Students who think critically have confidence and are able to explore the implications of the inferences that have been made. Based on the questions with the inference indicators in (Table 6) show that students' answers are incomplete, have not been able to collect things to form inferences and form opinions from the information provided, because students do not explain the impact on the paddy ecosystem if both prey are destroyed. Students must be able to apply good information contained in the problem to solve the problem, decide on action, find answers to the questions given or to reach reasonable inferences (Halpern, 2014).
Table 7. Examples of Students' Critical Thinking Skills (Evaluation)

\begin{tabular}{|c|c|}
\hline $\begin{array}{l}\text { Componen } \\
t\end{array}$ & Substance \\
\hline Question & $\begin{array}{l}\text { What are the effects that influence the } \\
\text { energy loss that occurs in each trophy of } \\
\text { the energy pyramid? }\end{array}$ \\
\hline \multirow[t]{4}{*}{ Answer } & 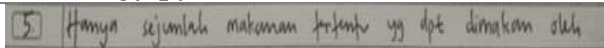 \\
\hline & $\square$ organime tropik dimbsimya \\
\hline & $\square$ \\
\hline & $\begin{array}{l}\text { Only certain amounts of food can be eaten } \\
\text { by the trophic organisms above it }\end{array}$ \\
\hline \multirow[t]{3}{*}{ Analysis } & $\begin{array}{l}\text { - Lack of understanding of } \\
\text { questions }\end{array}$ \\
\hline & $\begin{array}{l}\text { - Not able to compile statements } \\
\text { - Has not been able to evaluate } \\
\text { issues or problems }\end{array}$ \\
\hline & $\begin{array}{l}\text { - Cannot make logical judgments } \\
\text { on each tropic }\end{array}$ \\
\hline
\end{tabular}

Critical thinking refers to self-discipline thinking, where a thinker scoring and evaluates relevant information related to a situation (Abrami et al., 2015) The students' answers in (Table 7) show that students have not been able to evaluate problems or problems. Student's answers are incomplete, only answer one cause. While what is needed is to evaluate the cause of the reduction of energy in each trophy of the energy pyramid.

Critical thinking is an activity of thinking actively, carefully and and supported by clear reasons and is able to provide further explanation (Fisher, 2001; Alatas, 2014). Students' answers to the questions (Table 8) show that students are able to state the results but are unable to provide further explanation. Student answers do not support the procedure or explain the process coherently. Students are still having difficulty presenting opinions, explaining and developing answers in their own language. So, it can be concluded that students have not been able to explain answers in detail. 
Table 8. Examples of Students' Critical Thinking Skills (Explaining)

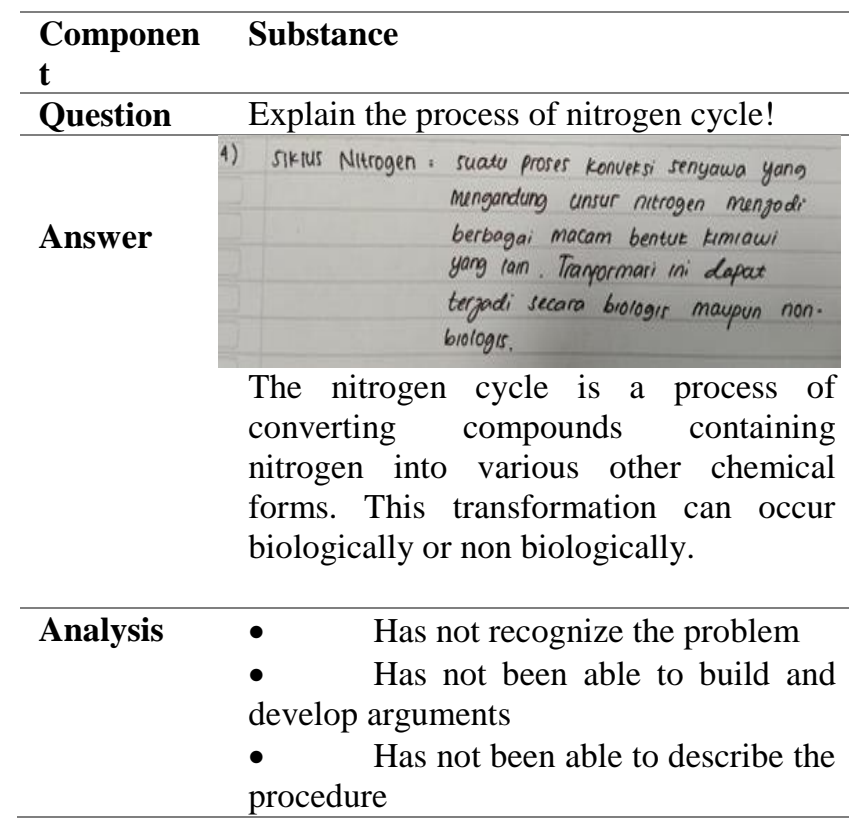

This is in line with research conducted by (Luzyawati, 2017) that students are only able to give simple explanations and have difficulty giving further explanations. The achievement of explanatory indicators is low because of several factors including, students lack understanding of the contents of the questions, it is still difficult to analyze and evaluate information, and students are accustomed to learning by only receiving information from the teacher, so most students have difficulty when faced with a problem that demands to give an explanation advanced. Students are very important to give explanations to strengthen their understanding (Herlanti, 2017). For this reason, the teacher must explain and instruct the learning appropriately so that the student's explanation is correct and not confusing.

Critical thinking is selfguided, skills in recognizing one's own weaknesses and strengths, fair and disciplined thinking, reconstructing thoughts from one's own views and ideas of others to reach the level of thinking at the highest quality (Paul \& Elder, 2007). Based on the answers to the questions in (Table 9), students are aware of the importance of forests for living things, students are able to find ways or solutions to deal with problems.
Table 9. Examples of Students' Critical Thinking Skills (Self-Regulation)

\begin{tabular}{|c|c|}
\hline $\begin{array}{l}\text { Componen } \\
\mathbf{t}\end{array}$ & Substance \\
\hline Question & $\begin{array}{l}\text { Mining activities by clearing forest land } \\
\text { cause forest destruction and can no longer } \\
\text { be overgrown with plants. Pollution } \\
\text { arising from mining activities damages the } \\
\text { forest ecosystem. Though forests are a } \\
\text { source of oxygen for humans and animals. } \\
\text { As a student, what things can you do to } \\
\text { respond these problems? }\end{array}$ \\
\hline \multirow[t]{2}{*}{ Answer } & $\begin{array}{l}\text { 6. - tidak membuang-buang kertas } \\
\text { - menggunakan transportasi umum } \\
\text { - meimbuang sampah pada tempatnya } \\
\text { - menanam pohon }\end{array}$ \\
\hline & $\begin{array}{l}\text { - don't waste paper } \\
\text { - use public transportation } \\
\text { - throw garbage in its place } \\
\text { - plant tree. }\end{array}$ \\
\hline Analysis & $\begin{array}{l}\text { Students able to find ways to deal with } \\
\text { problems, able to provide logical answers } \\
\text { in responding to problems, and be able to } \\
\text { find solutions and make assumptions }\end{array}$ \\
\hline
\end{tabular}

Students' critical thinking is low because the teacher has not accustomed students to think critically which results in students accustomed to getting all information from the teacher. Critical thinking skills are very important in science education. Students' skills in critical thinking do not develop spontaneously. The teacher has an important role in developing students' thought processes. This is in line with (Vanicheva et al., 2015) that critical thinking in science is very important because every data from the facts of science is always updated at all times and in this renewal a critical thinking process is needed.

Based on the results of the study, students' mastery of the ecosystem concept gained an average of 61.10 which indicates that the mastery of the student ecosystem concept is still low because it has not reached the graduation value standard. The following is presented the average acquisition of each indicator of student' mastery concept of ecosystems.

Table 10. Percentage of Mastery Concepts

\begin{tabular}{ll}
\hline Indicator & Average \\
\hline Remembering & 74.32 \\
\hline Understanding & 71.62 \\
\hline Applying & 64.86 \\
\hline Analyzing & 47.88 \\
\hline Evaluating & 55.86 \\
\hline Creating & 51.35 \\
\hline
\end{tabular}


The achievement of the score in (Table 10) shows that the 'remembering' indicator obtained the highest average value of 74.32 , while the indicator in the lowest category was analyzing 'with an average of 47.88. Based on the results of the study, the average of student' mastery of the ecosystems concept is 61.10 which falls into the low category and only $35 \%$ of students are able to master the concept of ecosystems. The aspect of "remembering" is an indicator with the highest value but it is still relatively low based on the range of scores. Remembering is the lowest cognitive aspect. It shows, if the achievement of the value of $\mathrm{C} 1$ (remembering) is still low then it will be increasingly difficult to achieve other aspects.

Recalling the ecosystem material that was studied in middle school was not easy. Each student has a different memory for a material. Al-Hasra High School students come from different junior high schools. This will further distinguish the memory of students because they are taught by different teachers. Students who previously came from public junior high schools will remember the material more than students who previously came from school with religion basic, like muslim boarding school or Islamic junior high school, because science learning is more focused and detailed in public junior high (general).

In some cases, material already exists or is available in memory, but it is difficult to recall. Sometimes the material cannot be immediately obtained when needed. Not that the material does not exist, it's just that students are not able to find it (recall it), so it depends on how the information is read, recorded, and stored in memory (Higbee, 2001). Each student needs a different time duration in recalling the material he has learned and mastering concepts. This is in line with (Adlim et al., 2017; Guskey, 2015) students are less able to read and interpret meaning, and the teacher divides students into groups and then teaches each unit of concept in the same way and in the same duration of time are factors that lead to low mastery of student concepts.

Based on interviews with several Al-Hasra high school students who came from different levels of junior high school, the teacher had a different way of teaching so that the level of student achievement in the material was also different. The number of natural science material at junior high level, one of which is ecosystem material, makes the teacher divide students into several groups, then divide different sub-materials in each group to be discussed by each group, so students only master the sub-material discussed in the group. In the end, this also has an impact when students sit in high school, where ecosystem material re-enters Biology learning in high school and is increasingly complex compared to ecosystem material in junior high school. Students are not able to remember the ecosystem material properly.

Based on the results of the study, the average score of students' knowledge about the material components of the ecosystem was 77.70, interactions in the ecosystem 54.73, energy flow 56.90, and biogeochemical cycles 39.24. In this case it appears that students have not mastered the initial concept so that from the first sub-material to the final sub-material decreases. The first sub material to the end sub material has a relationship. If you do not understand the components of the ecosystem, it will be increasingly difficult to understand the material interactions in the ecosystem, let alone having to master all the subchapters that exist in the ecosystem material. In this case, the teacher must be aware of the shortcomings in learning and observant in overcoming problems, because learning ecosystems in students greatly contribute in protecting the environment today until later.

Management of good learning in biology is to sort the material that must be studied first or prioritized. The ordering of biological material will lead to an understanding of biological concepts so that it is easier to master the o verall concept (Parrott \& Rubinstein, 2015). There are two same indicators in assessing the level of achievement of critical thinking skills and mastery concepts, namely analyzing and evaluating. Analyzing the critical thinking skills obtained an average of 42.57, while the mastery concepts of 47.88 . Evaluate the critical thinking skills by 45.27 , while the mastery concepts is 54.05. In this case, the test in the form 
of an essay is more difficult for students than multiple choices.

\section{CONCLUSION}

Based on the results of the study, it can be concluded that the average critical thinking skills and mastery of students' ecosystem concepts are 51.69 and 61.10 respectively which are in the low category because they have not yet reached the minimum passing standard. Students have not been able to classify meanings on aspects of interpretation. It is still low to recognize and reason statements in aspects of analysis. It has not been able to draw the right conclusions due to lack of attention to the question. Has not critical in assessing a statement so students are only able to explain briefly and have difficulty explaining or developing answers. Some students have been able to improve themselves and are aware of the importance of protecting the environment in aspects of self-regulation.

Students'mastery concept of ecosystems is low because each student has a different time duration in mastering the material. Some students did not understand the sub ecosystem material which first found it difficult to understand the subsequent ecosystem sub material. Students have not been able to meet the objectives of learning ecosystem well. This will have an impact on student learning independence, so that it will continue to depend on the teacher.

\section{REFERENCES}

Abrami, P. C., Bernard, R. M., Borokhovski, E., Waddington, D. I., Wade, C. A., \& Persson, T. (2015). Strategies for Teaching Students to Think Critically: A Meta-Analysis. Review of Educational Research, 85(2), 275-314. https://doi.org/10.3102/0034654314551063

Adlim, M., Wilyta, I., \& Hasan, M. (2017). Model Analisis Penyebab Rendahnya Penguasan Konsep yang Diuji dalam Ujian Nasional (Kajian pada Materi Ilmu Kimia pada Siswa SMA/MA Sekitar Kampus Unsyiah). 11(1), 15-27. https://doi.org/10.13170/jp.11.1.8103
Alatas, F. (2014). Hubungan Pemahaman Konsep dengan Keterampilan Berpikir Kritis melalui Model Pembelajaran Treffinger pada Mata Kuliah Fisika Dasar. EDUSAINS, 6(1), 8996.

Anderson, L. W., Krathwohl, D. R., \& Bloom, B. S. (2002). A taxonomy for learning, teaching, and assessing: a revision of Bloom's taxonomy of educational objectives (Vol. 41, Issue 4). http://books.google.com/books?id=JPkXAQ AAMAAJ\&pgis $=1$

Bezanilla, M. J., Fernández-Nogueira, D., Poblete, M., \& Galindo-Domínguez, H. (2019). Methodologies for Teaching-Learning Critical Thinking in Higher Education: The Teacher's View. Thinking Skills and Creativity, $\quad 100584, \quad 1-17$. https://doi.org/10.1016/j.tsc.2019.100584

Bonnett, M. (2016). Environmental Education and the Issue of Nature. Journal of Curriculum Studies, 39(6), 707-721. https://doi.org/10.1080/00220270701447149

Changwong, K., Sukkamart, A., \& Sisan, B. (2018). Critical Thinking Skill Development: Analysis of A New Learning Management Model for Thai High Schools. Journal of International Studies, 11(2), 37$48 . \quad$ https://doi.org/10.14254/2071$8330.2018 / 11-2 / 3$

Crossman, N. D., Bryan, B. A., \& Summers, D. M. (2011). Carbon Payments and Low-Cost Conservation. Conservation Biology, 25(4), 835-845. https://doi.org/10.1111/j.15231739.2011.01649.x

Douglas, I. (2017). Flooding in African Cities, Scales of Causes, Teleconnections, Risks, Vulnerability and Impacts. International Journal of Disaster Risk Reduction, 26, 3442.

https://doi.org/10.1016/j.ijdrr.2017.09.024

Facione, P. A. (2011). Critical Thinking: What It Is and Why It Counts. Insight Assessment, ISBN 13: 978-1-891557-07-1., 1-28. 
Fajrianthi, Hendriani, W., \& Septarini, B. G. (2016). Pengembangan Tes Berpikir Kritis dengan Pendekatan Item Response Theory. Jurnal Volume, Evaluasi Pendidikan, 20(1), 45-55.

Franco, A. R., Costa, S., \& Butler, H. A. (2017). Assessment of Undergraduates ' Real-World Outcomes of Critical Thinking in Everyday Situations. Psychological Reports, 120(4), 707-720. https://doi.org/10.1177/0033294117701906

Geçit, Y., \& Akarsu, A. H. (2017). Critical Thinking Tendencies of Geography Teacher Candidates in Turkey. Universal Journal of Educational Research, 5(8), 1362-1371. https://doi.org/10.13189/ujer.2017.050809

Gojkov, G., Stojanovi, A., \& Gojkov, A. (2015). Critical Thinking Of Students - Indicator Of Quality In Higher Education. Procedia Social and Behavioral Sciences, 191, 591596.

https://doi.org/10.1016/j.sbspro.2015.04.501

Guskey, T. R. (2015). Mastery Learning. In International Encyclopedia of Social \& Behavioral Sciences (Second Edi, Vol. 14). Elsevier. https://doi.org/10.1016/B978-0-08097086-8.26039-X

Harahap, L. J., Ristanto, R. H., \& Komala, R. (2020a). Evoking 21st -Century Skills: Developing Instrument of Critical Thinking Skills and Mastery of Ecosystem Concepts. Tadris: Jurnal Keguruan dan Ilmu Tarbiyah, 5(1), 27-41. DOI: 10.24042/tadris.v5i1.5943

Harahap, L. J., Ristanto, R. H., \& Komala, R. (2020b). Getting Critical Thinking about Ecosystem: How Impact and Responses of Students about the CirGi Learning Model?. Biosfer: Jurnal Pendidikan Biologi, 13(1), 86-100. https://doi.org/10.21009/biosferjpb.v13n1.86 $-100$

Herlanti, Y. (2017). An Analysis On Pedagogy Content Islamic Knowledge of Indonesian Qualification Framework in Biology Education Program. TARBIYA: Journal of
Education in Muslim Society, 4(2), 176-183. https://doi.org/10.15408/tjems.v4i2.6751

Hutcheson, W., Hoagland, P., \& Jin, D. (2018). Valuing Environmental education as a Cultural Ecosystem Service at Hudson River Park. Ecosystem Services, 31, 387-394. https://doi.org/10.1016/j.ecoser.2018.03.005

Komala, R., Suryanda, A., \& Lismana, Diana, D. (2016). Pengembangan Paludarium Sebagai Media Pembelajaran Biologi Pokok Bahasan Ekosistem di SMA. Biosfer: Jurnal Pendidikan Biologi, 9(1), 10-14. https://doi.org/10.21009/biosferjpb.9-1.2

Lamidi, B. T., Oyelekan, O. S., \& Olorundare, A. S. (2015). Effects of Mastery Learning Instructional Strategy on Senior School Students' Achievement in the Mole Concept. Electronic Journal of Science Education, 19(5), 1-20.

Luzyawati, L. (2017). Analisis Kemampuan Berpikir Kritis Siswa SMA Materi Alat Indera melalui Model Pembelajaran Inquiry Pictorial Riddle. Edusains: Jurnal Pendidikan Sains \& Matematika, 5(2), 9-21.

Parrott, J. S., \& Rubinstein, M. L. (2015). Metacognition and Evidence Analysis Instruction: An Educational Framework and Practical Experience. Systematic Reviews, 4(112), 1-8. https://doi.org/10.1186/s13643015-0101-8

Permana, F. H., \& Chamisijatin, L. (2019). Biosfer: Jurnal Pendidikan Biologi. Biosfer: Jurnal Pendidikan Biologi, 12(1), 58-69. https://doi.org/10.21009/biosferjpb.v12n1.58 $-69$

Purwanto, M. N. (2002). Prinsip-Prinsip dan Teknik Evaluasi Pengajaran. Bandung: PT Remaja Rosdakarya.

Ristanto, R. H., Zubaidah, S., Amin, M., \& Rohman, F. (2018). From a reader to a scientist: developing cirgi learning to empower scientific literacy and mastery of biology concept. Biosfer: Jurnal Pendidikan Biologi, $\quad 11(2), \quad 90-100$. 
https://doi.org/10.21009/biosferjpb.v11n2.90 $-100$

Soirwan, \& Nyeneng, I. D. P. (2013). Pengaruh Kemampuan Berpikir Kritis Terhadap Penguasaan Konsep Melalui Pembelajaran Kooperatif Tipe STAD. Jurnal Pembelajaran Fisika, 1(3), 1-12.

Torkar, G., \& Krašovec, U. (2019). Students ' Attitudes Toward Forest Ecosystem Services , Knowledge About Ecology, and Direct Experience with Forests. Ecosystem Services, $\quad 37, \quad 1-8$. https://doi.org/10.1016/j.ecoser.2019.100916

Vanicheva, T., Kah, M., \& Ponidelko, L. (2015). Critical Thinking Within The Current Framework of ESP Curriculum in Technical Universities of Russia. Procedia - Social and
Behavioral Sciences, 199, 657-665. https://doi.org/10.1016/j.sbspro.2015.07.595

Wilson, J. S. (2017). Promoting Critical Thinking in General Biology Courses: The Case of the White Widow Spider. Journal on Empowering Teaching Excellence, 1(2), 52 61.

https://doi.org/https://doi.org/10.26077/jmb7 -zh62

Yeh, V. J., Sherwood, G., Durham, C. F., Kardongedgren, S., Schwartz, T. A., \& Beeber, L. S. (2019). Online Simulation-Based Mastery Learning with Deliberate Practice : Developing Interprofessional Communication Skill. Clinical Simulation in Nursing, 32 , $27-38$ https://doi.org/10.1016/j.ecns.2019.04.005. 